\begin{tabular}{|c|c|c|}
\hline ENGINEERING CHANGE NOTICE & Pago 1 of 2 & 1. ECN 630488 \\
\hline
\end{tabular}

\begin{tabular}{|c|c|c|c|c|c|c|}
\hline \multirow{3}{*}{$\begin{array}{l}\text { 2. ECN Category } \\
\text { (mark one) } \\
\text { Supplemental } \\
\text { Oirect Revision } \\
\text { Change ECN } \\
\text { Temporary } \\
\text { Standby } \\
\text { Supersedure } \\
\text { Cancel/Noid }\end{array}$} & \multirow{3}{*}{$\begin{array}{r}{[]} \\
{[\times]} \\
{[]} \\
{[1]} \\
{[1} \\
{[1]} \\
{[1]}\end{array}$} & \multicolumn{2}{|c|}{$\begin{array}{l}\text { 3. Originator's Name, Organization, MSIN, } \\
\text { and Telephone No. } \\
\text { A. M. Ta } 7 \text { man, LES, } 86000 \text {, } \\
\text { H6-30, 376-0986 }\end{array}$} & \multicolumn{2}{|c|}{$\begin{array}{l}\text { 3a. USa Required? } \\
{[] \text { Yes }[X] \text { No }}\end{array}$} & $\begin{array}{l}\text { 4. Date } \\
09 / 04 / 96\end{array}$ \\
\hline & & \multicolumn{2}{|c|}{$\begin{array}{l}\text { 5. Project Title/No./Work order No. } \\
\text { Canister Storage Building } \\
\text { Natural Phenomena Hazards/LG070 }\end{array}$} & \multicolumn{2}{|c|}{$\begin{array}{c}\text { 6. Bldg./Sys./Fac. No. } \\
\text { Canister Storage } \\
\text { Building }\end{array}$} & $\begin{array}{l}\text { 7. Approval Designator } \\
\qquad E, S, Q\end{array}$ \\
\hline & & \multicolumn{2}{|c|}{$\begin{array}{l}\text { 8. Document Numbers Changed by this ECM } \\
\text { (includes sheet no. and rev.) } \\
\text { WHC-SD-SNF-DB-009, Rev. } 2\end{array}$} & \multicolumn{2}{|c|}{$\begin{array}{l}\text { 9. Related ECN No(s). } \\
191425,166794\end{array}$} & 10. Related PO No. \\
\hline \multirow{2}{*}{\multicolumn{2}{|c|}{$\begin{array}{l}\text { 11a. Modification Hork } \\
\text { [] Yes (fill out Blk. } \\
11 \mathrm{~b}) \\
\text { [X] No (NA B(ks. 11b, } \\
11 \mathrm{c}, 11 \mathrm{~d})\end{array}$}} & \multirow[t]{2}{*}{$\begin{array}{l}\text { 11b. Work Package } \\
\text { No. } \\
\text { N/A }\end{array}$} & \multicolumn{2}{|c|}{$\begin{array}{l}\text { 11c. Modification Work Complete } \\
\text { N/A }\end{array}$} & \multicolumn{2}{|c|}{$\begin{array}{l}\text { 11d. Restored to Originat Condi- } \\
\text { tion (Temp. or Standby ECN only) } \\
\text { N/A }\end{array}$} \\
\hline & & & Co & & $\cos$. & er Signa \\
\hline
\end{tabular}

12. Description of change

This revision incorporates an alternative method for providing tornado missile protection for all safety class and important to safety SSCs.

13a. Justification (mark one)

Criteria Change [] Design Improvement [ $X]$

As-Found [] Facilitate const []

[X] Enviromental [] Facility Deactivation []

13b. Justification Details

Revision incorporates alternative method for providing tornado missile protection.

14. Distribution (include name, MSIN, and no. of copies)

G. D. Bazinet, B4-55 C. R. Miska, R3-86

T. J. Conrads, B1-17

S. P. Reidel, H6-06

C. DeFigh-Price, R3-11

D. W. Duncan, B4-55

A. M. Tallman, H6-30 (5 copies)

L. J. Garvin, R3-85

C. A. Thompson, R3-85

A. G. Hosler, HO-50

J. E. Turnbaugh, R3-11

J. J. Irwin, $\mathrm{HO}-33$

A. M. Zaman, B1-10

Central Files, A3-88

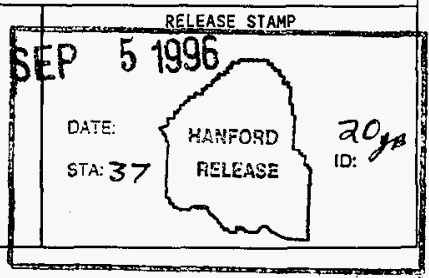

A-7900-013-2(11/94) GEF095 


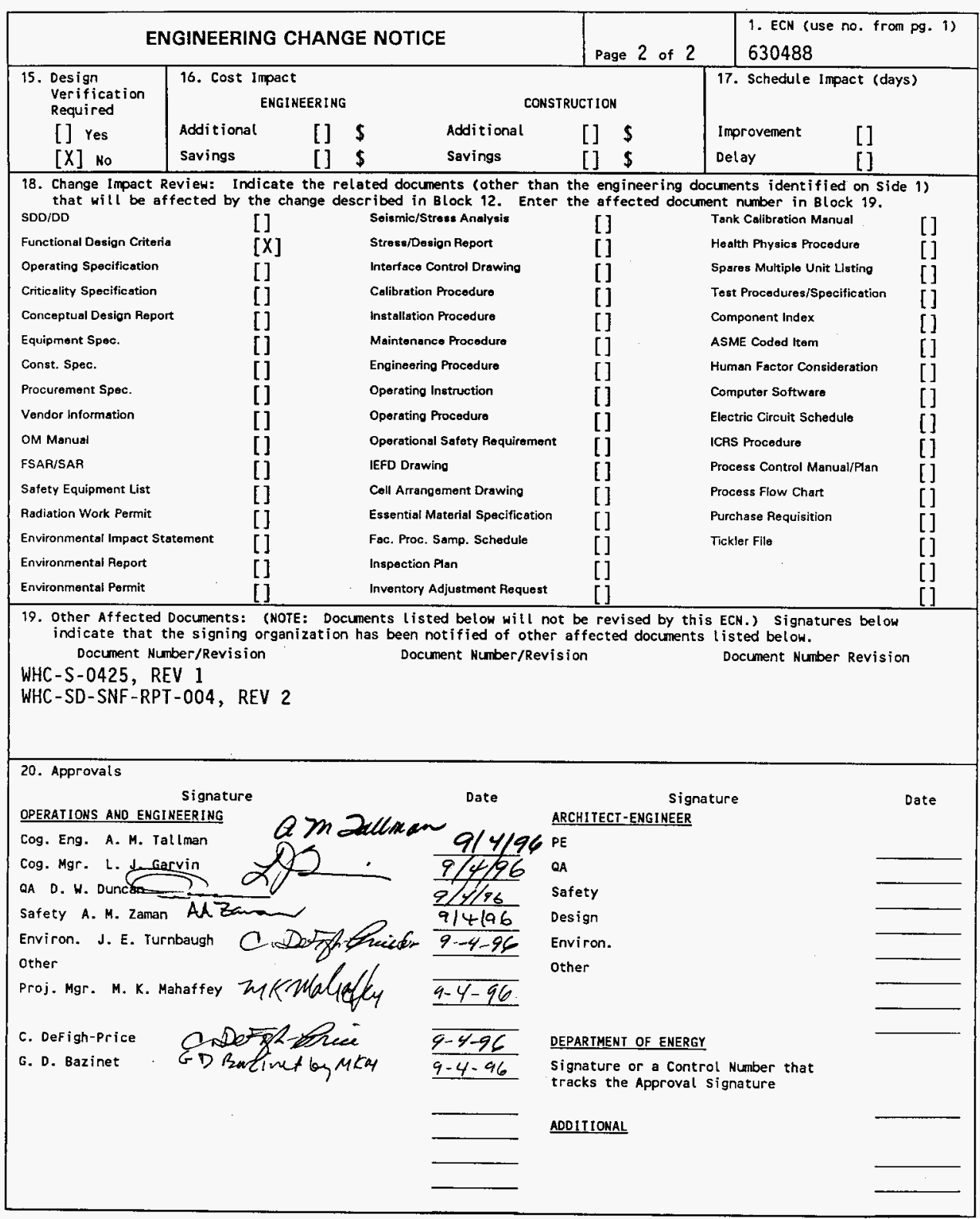




\title{
Canister Storage Building Natural Phenomena Hazards
}

\author{
Ann M. Tallman \\ Westinghouse Hanford Company, Richland, WA 99352 \\ U.S. Department of Energy Contract DE-AC06-87RL10930 \\ EDT/ECN: 630488 \\ Org Code: 86000 \\ B\&R Code: $39 E W 31354$ \\ UC: 2000 \\ Charge Code: LG070 \\ Total Pages: 44
}

Key Words: Natural phenomena hazards, design loads, seismic, ashfall, wind, tornado, snow, lightning.

Abstract: This document specifies the natural phenomena loads for the Canister Storage Building in the 200 East Area of the Hanford Site.

TRADEMARK DISCLAIMER. Reference herein to any specific comercial product, process, or service by trade name, trademark, manufacturer, or otherwise, does not necessarily constitute or imply its endorsement, recommendation, or favoring by the United states Government or any agency thereof or its contractors or subcontractors.

Printed in the United States of America. To obtain copies of this document, contact: WHC/BCS Document Control Services, P.0. 80x 1970, Mailstop H6-08, Richland WA 99352, Phone (509) 372-2420; Fax (509) 376-4989.
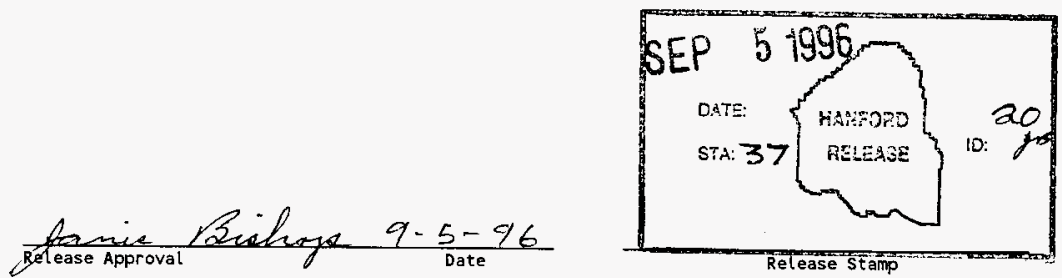

\section{Approved for Public Release}




\section{RECORD OF REVISION}

(1) Document Number

WHC-SO-SNF-DB-0O9

(2) Tisle

Canister Storage Building Natural Phenomena Hazards

CMANGE CONTROL RECORO

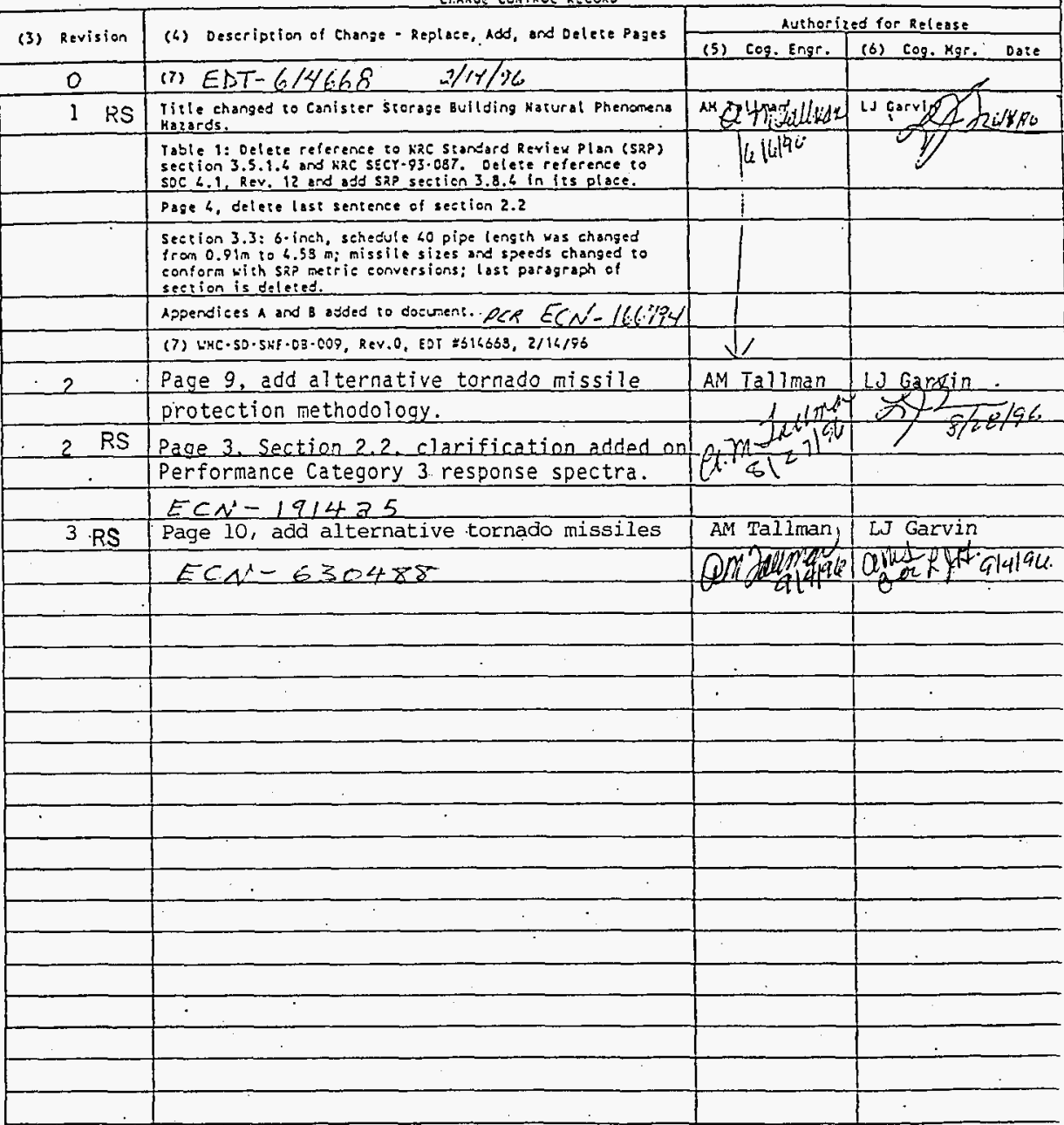


CANISTER STORAGE BUILDING

NATURAL PHENOMENA HAZARDS

WHC-SD-SNF-DB-009

Revision 3

September 1996 
WHC-SD-SNF-DB-009 REV 3

This page intentionally left blank. 
CONTENTS

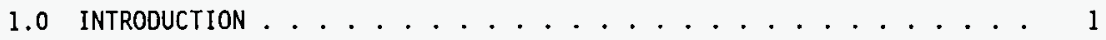

2.0 SEISMIC CRITERIA . . . . . . . . . . . . . . . 1

2.1 BACKGROUND . . . . . . . . . . . . . . 1

2.2 U.S. DEPARTMENT OF ENERGY DESIGN REQUIREMENTS ........ 3

3.0 WIND AND TORNADO CRITERIA ........................ 3

3.1 BACKGROUND ....................... 3

3.2 U.S. DEPARTMENT OF ENERGY DESIGN REQUIREMENTS . . . . . . . . 3

3.3 U.S. NUCLEAR REGULATORY COMMISSION DESIGN REQUIREMENTS . . . . 6

4.0 VOLCANIC ASH CRITERIA . . . . . . . . . . . . . 11

4.1 BACKGROUND . . . . . . . . . . . . . . 11

4.2 U.S. DEPARTMENT OF ENERGY DESIGN REQUIREMENTS . . . . . . . 12

4.3 U.S. NUCLEAR REGULATORY COMMISSION DESIGN REQUIREMENTS . . . 12

5.0 FLOOD CRITERIA . . . . . . . . . . . . . . . . . . 16

5.1 BACKGROUND . . . . . . . . . . . 16

5.2 U.S. DEPARTMENT OF ENERGY DESIGN REQUIREMENTS . . . . . . 16

5.3 U.S. NUCLEAR REGULATORY COMMISSION DESIGN REQUIREMENTS . . . . 17

6.0 LightNING . . . . . . . . . . . . . . . . . . . . . . . . . . . 17

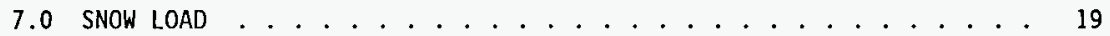

8.0 REFERENCES ......................... 19

\section{APPENDIXES}

A WNP-2, OPERATING LICENSE NPF-21, REQUEST FOR APPROVAL TO REVISE TORNADO DESIGN CRITERIA . . . . . . . . . A-1

B REVISION OF TORNADO DESIGN CRITERIA FOR THE WASHINGTON PUBLIC POWER SUPPLY SYSTEM (WPPSS) NUCLEAR PROJECT N0.2 (WNP-2) . . . . . . . . . . . . B B-1 


\section{LIST OF FIGURES}

1 Performance Category 3 Horizontal and Vertical Design Response Spectra with 5\% Damping at the Canister Storage Building Site . . . . 4

2 Canister Storage Building, Newmark and Hall Median Response Spectra at $0.35 \mathrm{~g}$ Horizontal and $0.23 \mathrm{~g}$ Vertical Compared to Performance Category 3 Spectra, $5 \%$ Damping .......... 5

3 Straight Wind and Tornado Hazards ............. 7

4 Annual Probability of One Centimeter or More of Volcanic Ash Accumulation in Washington and Oregon from Major Cascade

. Volcanoes ..................... 13

5 Annual Probability of Ten Centimeters or More of Volcanic Ash Accumulation in Washington and Oregon from Major Cascade Volcanoes ...................... 14

6 Cascade Range Volcanic Ash Hazard ................ 15

\section{LIST OF TABLES}

1 Canister Storage Building Safety-Class Natural Phenomena Design Loads ................... . . 2

2 Design Basis Loads for Ashfall Criteria . . . . . . . . . . 16

3 Extreme Precipitation Estimates for the Hanford Site . . . . . . . 18 


\section{LIST OF TERMS}

BP
CSB
DOE
NPH
NRC
PMP
SSC
Supply System
WNP-2

BP

DOE

$\mathrm{NPH}$

PMP

Supply System

WNP-2 before present

Canister Storage Building

U.S. Department of Energy

natural phenomena hazard

U.S. Nuclear Regulatory Commission

probable maximum precipitation structure, system, and component Washington Public Power Supply System

Washington Public Power Supply System Nuclear Plant 2 
WHC-SD-SNF-DB-009 REV 3

This page intentionally left blank. 


\section{CANISTER STORAGE BUILDING NATURAL PHENOMENA DESIGN HAZARDS}

\subsection{INTRODUCTION}

This document specifies natural phenomena hazard (NPH) loads for use in the design and construction of the Canister Storage Building (CSB), which will be located in the 200 East Area of the Hanford Site. U.S. Department of Energy (DOE) regulatory policy for these design and construction activities requires a level of nuclear safety comparable to that of U.S. Nuclear Regulatory Commission (NRC) licensed facilities. The DOE requirements are based on DOE Order 5480.28, Natural Phenomena Hazards Mitigation; and supporting standards, DOE-STD-1020-94, Natural Phenomena Hazards Design and Evaluation Criteria for Department of Energy Facilities; DOE-STD-1022-94, Natura7 Phenomena Hazards Site Characteristics Criteria; and DOE-STD-1023-95, Natural Phenomena Hazards Assessment Criteria. DOE Order 5480.28 requires that each structure, system, and component be assigned to one of five performance categories based on safety class and hazard category. Each performance category has an associated NPH goal that serves as a measure of the level of protection against potential natural phenomena. The CSB has been designated a Performance Category 3 facility (WHC 1996). The NRC requirements are based on Title 10, Code of Federal Regulations, Part 72, "Licensing Requirements for the Independent Storage of Spent Nuclear Fuel and High-Level Radioactive Waste" (10 CFR 72).

With the exception of seismic design criteria, the compliance to both NRC and DOE requirements is accomplished by using the more stringent of the requirements for the design. The seismic design for this complex is thoroughly discussed in WHC-SD-SNF-DB-004, Spent Nuclear Fuel Project Seismic Design Criteria (WHC 1996). The NPH design loads and the application documents to be followed for the CSB are summarized in Table 1 . The remainder of this document provides more detail on NPH loads and reviews the derivation of these loads.

\subsection{SEISMIC CRITERIA}

\subsection{BACKGROUND}

A comparison of the NRC and DOE seismic design requirements and a discussion of the CSB seismic design strategy are presented in WHC-SD-SNF-DB-004 (WHC 1996) and are not repeated here. The DOE seismic design requirements are being used for the CSB and are summarized in this section. 
Table 1. Canister Storage Building Safety-Class Natural Phenomena Design Loads.

\begin{tabular}{|c|c|c|}
\hline Hazard & Load & Application documents \\
\hline Seismic & $\begin{array}{l}\text { Median response spectra: } \\
0.35 \mathrm{~g} \text { horizontal } \\
0.23 \mathrm{~g} \text { vertical }\end{array}$ & $\begin{array}{l}\text { DOE Order } 5480.28^{\mathrm{b}} \\
\text { DOE Standard } 1020-94^{\mathrm{c}}\end{array}$ \\
\hline Straight wind & $\begin{array}{l}129 \mathrm{~km} / \mathrm{h}(80 \mathrm{mi} / \mathrm{h}) \text {, fastest mile at } 9 \mathrm{~m} \\
(30 \mathrm{ft})\end{array}$ & $\begin{array}{l}\text { ASCE-7-93 } \\
\text { DOE Standard 1020-94 (including missiles) }\end{array}$ \\
\hline Tornado & $\begin{array}{l}\text { Wind speeds } \\
322 \mathrm{~km} / \mathrm{h}(200 \mathrm{mi} / \mathrm{h}) \text { total } \\
257 \mathrm{~km} / \mathrm{h}(160 \mathrm{mi} / \mathrm{h}) \text { rotational } \\
64 \mathrm{~km} / \mathrm{h}(40 \mathrm{mi} / \mathrm{h}) \text { translational }\end{array}$ & $\begin{array}{l}\text { NRC Standard Review Plan } \\
\text { 3.3.2 Tornado Loading }\end{array}$ \\
\hline Volcanic ash & $117 \mathrm{~kg} / \mathrm{m}^{2}\left(24 \mathrm{lb} / \mathrm{ft}^{2}\right)$ ground ash load & $\begin{array}{l}\text { NRC Standard Review Plan } \\
\text { 3.8.4 0ther Seismic Category Structures }\end{array}$ \\
\hline Flooding & $\begin{array}{l}\text { Dry site for river flooding } \\
\text { Site drainage basin: } 19 \mathrm{~cm}(7.4 \text { in.) for } \\
\text { 6-hour probable maximum precipitation } \\
\text { Site drainage: } 23 \mathrm{~cm}(9.2 \text { in.) for } \\
\text { 6-hour probable maximum precipitation }\end{array}$ & 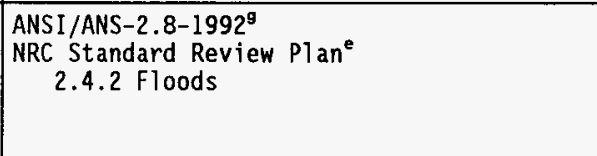 \\
\hline Lightning & $\begin{array}{l}\text { Lightning protection shall be provided for } \\
\text { the facility }\end{array}$ & NFPA $780^{h}$ \\
\hline Snow & $98 \mathrm{~kg} / \mathrm{m}^{2}\left(20 \mathrm{lb} / \mathrm{ft}^{2}\right)$ ground Toad & ASCE-7-93 \\
\hline
\end{tabular}

Nemark N. M and H J. Hall, 1978, Development of Criteria for Seismic Reviev of Selected Nuclear Pouer Plants, NUREG/CR-0098, U.S. Nuclear Regul atery Commission, Hashington D.C

DOE Order 5480.28, Natural Phenomena Hazards Mitigation, U.S. Department of Energy, Nashington, D.C.

DDE Standard 1020-94. Natural Phenomena Hazards Design and Evaluation Criteria for Department of Energy Facil ities, U.S. Department of Energy, Washington, D.C

ASCE, 1993, Minimm Design Loads for Building and Other Structures, ASCE-7-93, American Society of Civil Engineers, New York, New York. NRC, 1981, Standard Review Plan, NUREG-0800, U.S. Nuclear Regulatory Cormission, Hashington, D.C. Hansen, E. M., D. D. Fenn, P. Corrigan, J. L. Vogel, L. C. Schreiner, and R. W. Stodt, 1994, Probable Maximum Precipitation - Pacific Northwest States, Hydrometeorological Report No. 57, National Weather Service, Silver Spring, Maryland. lllinois.

ANSI/ANS, 1992, Determining Design Basis Flooding at Power Reactor Sites, ANSI/ANS-2.B-1992, American Nuclear Society, La Grange Park, 


\subsection{U.S. DEPARTMENT OF ENERGY DESIGN REQUIREMENTS}

Seismic design for Performance Category 3 projects shall follow DOE Order 5480.28 and supporting standard DOE-STD-1020-94, Chapter 2 and Appendix $C$. The accelerations 1 isted in DOE-STD-1020-94 are for illustration and should not be used for design. The seismic response spectra for Performance Category 3 at the location of the CSB (Geomatrix 1996) are shown in Figure 1. The spectral shapes for various damping levels are presented in WHC-SD-W236A-TI-002 (Geomatrix 1996). Performance Category 1 and 2 structures, systems, and components (SSCs) shall use the Uniform Building Code (ICB0 1994), Zone 2B, as discussed in DOE-STD-1020-94. The Uniform Building Code Zone $2 \mathrm{~B}$ acceleration of $0.20 \mathrm{~g}$ has a return period of approximately 1,200 years. Use standard occupancy rules for Performance Category 1 and essential facilities rules for Performance Category 2.

The CSB originally was designed to serve as part of the Hanford Waste Vitrification Plant and construction on the foundation has been partially completed (WHC 1992). Newmark and Hall (1978) median response spectra at $0.35 \mathrm{~g}$ horizontal and $0.23 \mathrm{~g}$ vertical were developed for this facility. Those response spectra are shown to envelop the Performance Category 3 response spectra for the location of the CSB (Figure 2). The CSB design response spectra are conservative compared to the Performance Category 3 design criteria and shall be used for the completion of the CSB design and construction following the design requirements of DOE-STD-1020-94.

\subsection{WIND AND TORNADO CRITERIA}

\subsection{BACKGROUND}

The Hanford Site is located in a semiarid region of southeastern Washington. The Cascade Range to the west greatly influences the climate of the Hanford Site by causing a "rain shadow" effect. This mountain range also serves as a source of cold air drainage, which has considerable effect on the wind regime of the Hanford Site.

Data have been collected since 1945 at the Hanford Meteorological Station, located between the Hanford Site's 200 East and West Areas. This includes wind data from six levels on a 125-m- (410-ft-) high tower. These data are supplemented with data from 26 monitoring stations on and around the Hanford Site. The most recent compilation of these data is in PNL-9809, Hanford Site Climatological Data Summary 1993 with Historical Data (Hoitink and Burk 1994).

\subsection{U.S. DEPARTMENT OF ENERGY DESIGN REQUIREMENTS}

Two probabilistic wind hazard assessments have been completed for the Hanford Site. The first assessment was completed by Lawrence Livermore National Laboratory and reported in UCRL-53526, Natural Phenomena Hazards Modeling Project: Extreme Wind/Tornado Hazard Models for Department of Energy Sites (Coats and Murray 1985). This assessment was based on more than 
Figure 1. Performance Category 3 Horizontal and Vertical Design Response Spectra with 5\% Damping at the Canister Storage Building Site.

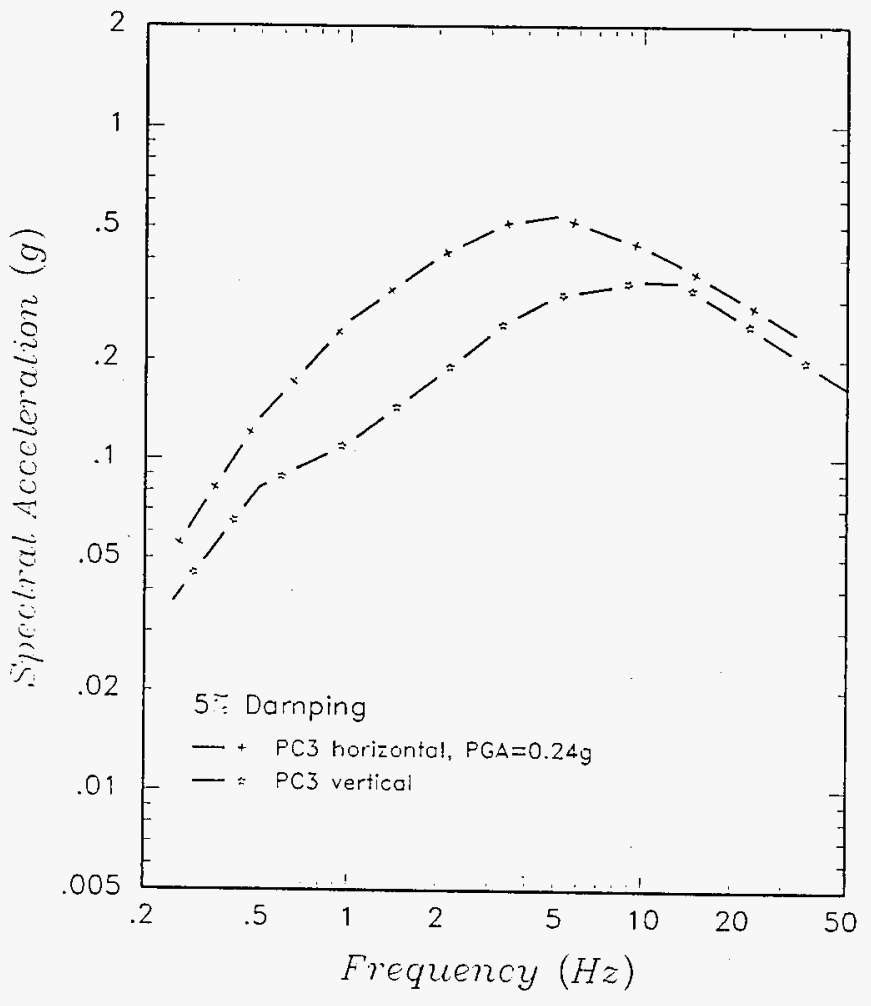


Figure 2. Canister Storage Building, Newmark and Hall Median Response Spectra at $0.35 \mathrm{~g}$ Horizontal and $0.23 \mathrm{~g}$ Vertical Compared to Performance Category 3 Spectra, 5\% Damping.

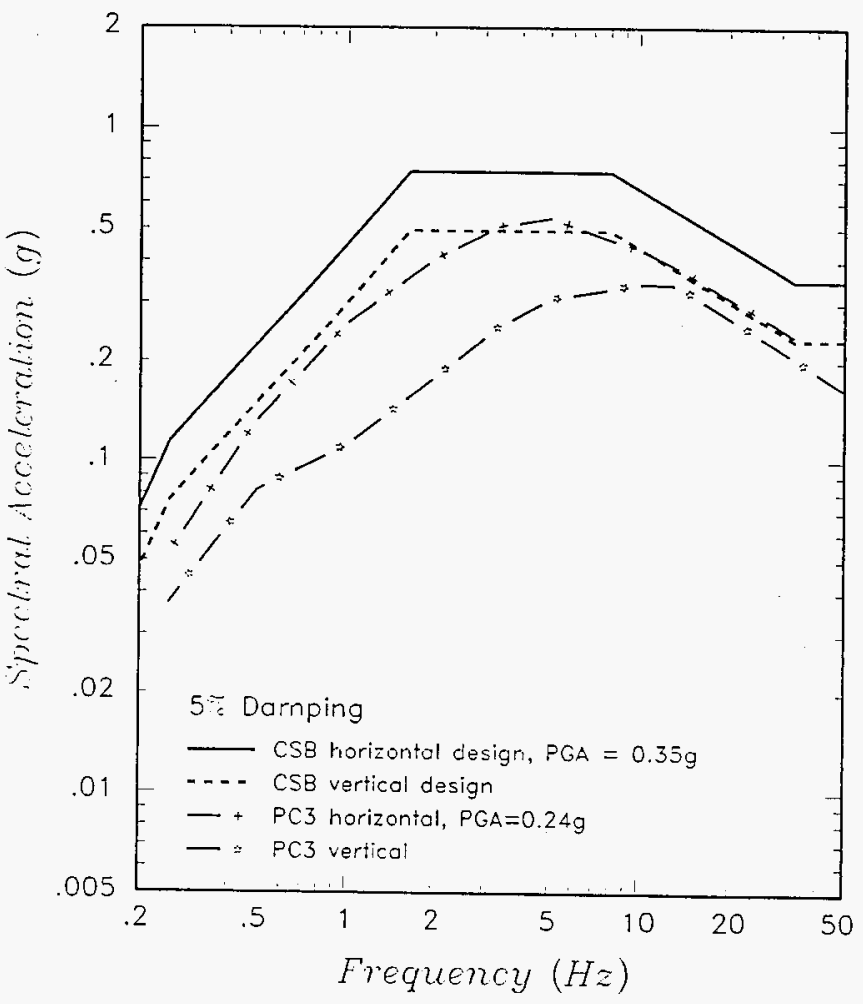


30 years of pre-1979 Hanford Site wind data. The results are shown in Figure 3 and are the basis for the recommended wind speeds for the Hanford Site listed in DOE-STD-1020-94, Table 3-2. The wind missiles are listed in DOE-STD-1020-94, Table 3-1.

A second study, NUREG/CR-4492, Methodology for Estimating Extreme Winds for Probabilistic Risk Assessment (Ramsdell et a1. 1986), describes a procedure for estimating extreme wind probabilities. The application of this methodology to Hanford Site data, including post-1979 data, resulted in the hazard curves shown in Figure 3 . There are no known local meteorological events or changes in methodology since 1986 that would cause significant changes to the Hanford Site wind hazard.

The wind hazard annual probability of exceedance for Performance Categories 1 and 2 is $2 \times 10^{-2}$ (DOE-STD-1020-94). On Figure 3 , this is about $25 \mathrm{~m} / \mathrm{s}(55 \mathrm{mi} / \mathrm{h})$ on the Coats-and-Murray curve and about $26 \mathrm{~m} / \mathrm{s}(58 \mathrm{mi} / \mathrm{h})$ on the Ramsde11-and-0thers curve. However, a minimum design wind speed of $31.3 \mathrm{~m} / \mathrm{s}(70 \mathrm{mi} / \mathrm{h})$ is required by American Society of Civil Engineers in ASCE-7-93, Minimum Design Loads for Building and Other Structures (ASCE 1993), and recommended by DOE-STD-1020-94. Therefore, the Hanford Site design basis wind speed for Performance Categories 1 and 2 is $31.3 \mathrm{~m} / \mathrm{s}(70 \mathrm{mi} / \mathrm{h})$. All wind speeds are fastest-mile speeds at $9 \mathrm{~m}(30 \mathrm{ft})$ off the ground.

The straight wind hazard exceedance probability for Performance Category 3 is $1 \times 10^{-3}$. On Figure 3 , this is approximately $30 \mathrm{~m} / \mathrm{s}(67 \mathrm{mi} / \mathrm{h})$ (Coats and Murray 1985) and $32 \mathrm{~m} / \mathrm{s}(72 \mathrm{mi} / \mathrm{h}$ ) (Ramsdell et al. 1986). In DOE-STD-1020-94, the minimum straight wind speed for Performance Category 3 design is $35.8 \mathrm{~m} / \mathrm{s}(80 \mathrm{mi} / \mathrm{h})$, which is higher than either of the wind hazard studies and is, therefore, the design basis for the Site. A $6.81 \mathrm{~kg}$ (15 1b) timber plank missile, $0.61 \mathrm{~m} \times 1.22 \mathrm{~m}$ ( $2 \mathrm{ft} \times 4 \mathrm{ft}$ ), is applied to Performance Category 3 SSCs at $22.4 \mathrm{~m} / \mathrm{s}(50 \mathrm{mi} / \mathrm{h})$ to a height of $9 \mathrm{~m}(30 \mathrm{ft})$. These wind criteria are greater than NRC requirements and are applied to the CSB.

The intersection of the straight wind and tornado hazard curves determines whether tornadoes should be included in the design and evaluation criteria (Coats and Murray 1985). If the exceedance probability at the intersection is less than $2 \times 10^{-5}$, straight winds control the design criteria. In Figure 3 , this intersection is at $3 \times 10^{-6}$ (Coats and Murray 1985) and $8 \times 10^{-6}$ (Ramsdell et a1. 1986). Therefore, following DOE guidance, the Hanford Site does not have a DOE design basis tornado.

\subsection{U.S. NUCLEAR REGULATORY COMMISSION DESIGN REQUIREMENTS}

The guidance in 10 CFR 72 with respect to straight wind and tornado hazard mitigation is very general and nonprescriptive (10 CFR 72.122[b]). The Standard Review Plan section on wind loading (NRC 1981,3.3.1) is specific and serves as a basis for determining appropriate straight wind and tornado values for the CSB because it has been accepted by the NRC for issuing the materials licenses for such facilities. The 100-year, fastest-mile wind speed is used for the straight wind calculations using American Society of Civil Engineers methodology (ASCE 1993, ASCE 1961). The 100-year, fastest-mile wind at the 


\section{WHC-SD-SNF-DB-009 REV 3}

Figure 3. Straight Wind and Tornado Hazards.

Wind Speed (meters/sec)

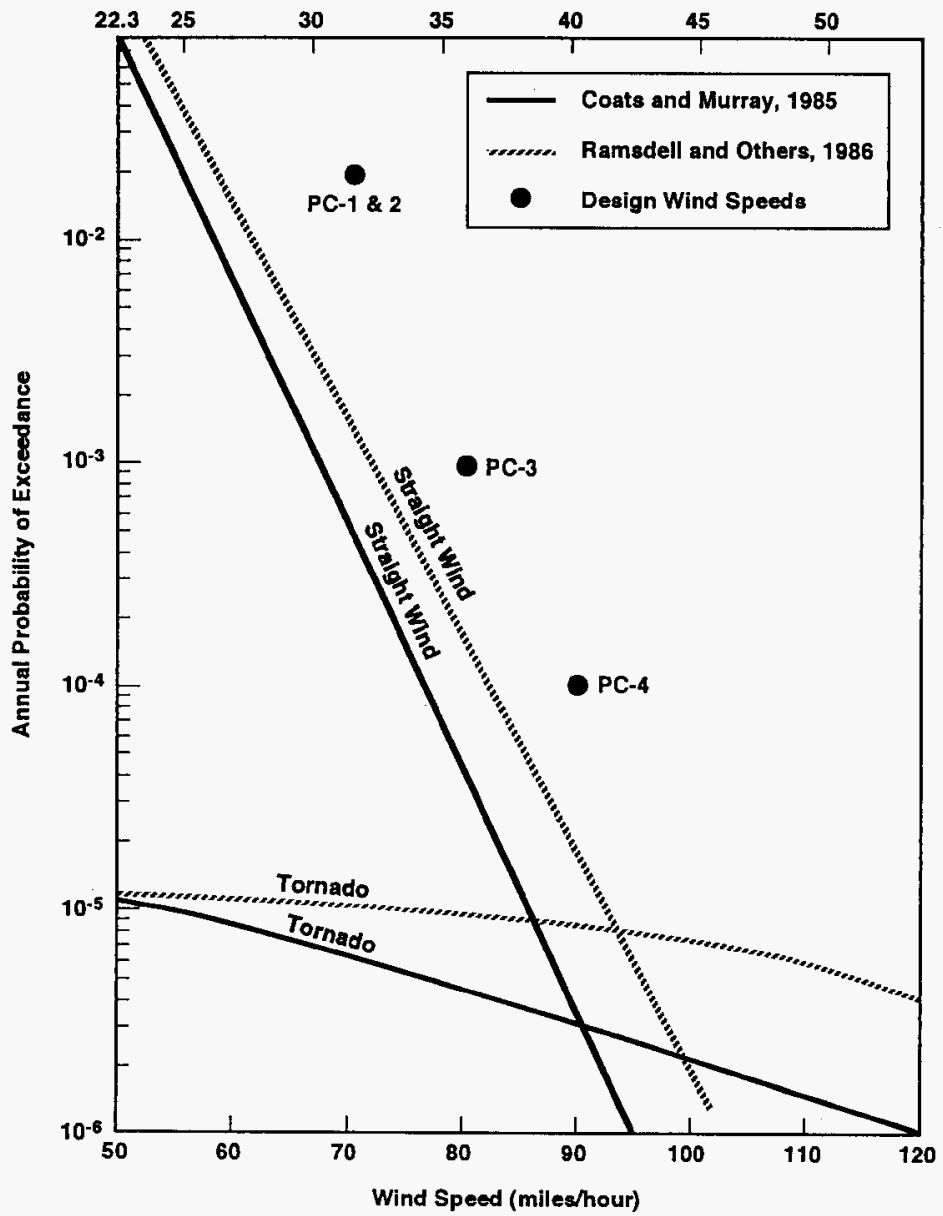

H95120284.1 CVDS 
Hanford Site is about $105 \mathrm{~km} / \mathrm{h}(65 \mathrm{mi} / \mathrm{h})$ (Figure 3). However, because DOE-STD-1020-94 requires a minimum of $129 \mathrm{~km} / \mathrm{h}(80 \mathrm{mi} / \mathrm{h})$ for Performance Category 3, the higher DOE value will be used for the design of the CSB.

Washington Public Power Supply System (Supply System) Nuclear Plant 2 (WNP-2), located on property with in the boundaries of the Hanford Site, was licensed to use tornado design wind speeds of $483 \mathrm{~km} / \mathrm{h}(300 \mathrm{mi} / \mathrm{h})$ rotatjonal and $97 \mathrm{~km} / \mathrm{h}(60 \mathrm{mi} / \mathrm{h})$ translational, with a pressure drop of $2,109 \mathrm{~kg} / \mathrm{m}^{2}$ $\left(3 \mathrm{lb} / \mathrm{in}^{2}\right)$ occurring at $703 \mathrm{~kg} / \mathrm{m}^{2} / \mathrm{s}\left(1.0 \mathrm{lb} / \mathrm{in}^{2} / \mathrm{s}\right)$. These wind speeds are higher than would be required by Regulatory Guide 1.76, Design Basis Tornado for Nuclear Power Plants (NRC 1974). Regulatory Guide 1.76 indicates that the Hanford Site is in tornado Region III for which the criteria are $305 \mathrm{~km} / \mathrm{h}$ $(190 \mathrm{mi} / \mathrm{h})$ rotational and $80 \mathrm{~km} / \mathrm{h}(50 \mathrm{mi} / \mathrm{h})$ translational, with a $1,055 \mathrm{~kg} / \mathrm{m}^{2}$ $\left(1.5 \mathrm{lb} / \mathrm{in}^{2}\right)$ pressure drop at $422 \mathrm{~kg} / \mathrm{m}^{2} / \mathrm{s}\left(0.6 \mathrm{lb} / \mathrm{in}^{2} / \mathrm{s}\right)$. The NRC staff have proposed dividing the United States into two regions and making the total rotational and translation wind speeds for sites west of the Rocky Mountains $322 \mathrm{~km} / \mathrm{h}(200 \mathrm{mi} / \mathrm{h})$ (NRC 1993). The basis for this consideration is a tornado hazards study, NUREG/CR-4461, Tornado Climatology of the Contiguous United States (Ramsdell and Andrews 1986). The Supply System requested (Parrish 1995; see Appendix A) a revision of the WNP-2 tornado criteria based upon the NRC staff's proposal for tornado wind speeds west of the Rocky Mountains (NRC 1993) and on the staff's acceptance of the design basis tornado characteristics in NUREG-1503, Final Safety Evaluation Report Related to the Certification of the Advanced Boiling Water Reactor Design (NRC 1994). The impact velocities for the proposed tornado missile spectrum based on the reduced wind speed of $322 \mathrm{~km} / \mathrm{h}(200 \mathrm{mi} / \mathrm{h})$ were calculated by the Supply System. The NRC accepted the proposed lower tornado missile criteria (Clifford 1996; see Appendix B). The CSB tornado design requirements, including design missiles, are listed below:

- Wind speed

- $322 \mathrm{~km} / \mathrm{h}(200 \mathrm{mi} / \mathrm{h})$ total

- $257 \mathrm{~km} / \mathrm{h}(160 \mathrm{mi} / \mathrm{h})$ rotational

- $64 \mathrm{~km} / \mathrm{h}(40 \mathrm{mi} / \mathrm{h})$ translational

- Pressure drop

- 6,205 Pa $\left(0.901 \mathrm{~b} / \mathrm{in}^{2}\right)$ at $2,068 \mathrm{~Pa} / \mathrm{s}\left(0.30 \mathrm{lb} / \mathrm{in}^{2} / \mathrm{s}\right)$

- Missiles

- Wood plank

$52 \mathrm{~kg}(1151 \mathrm{~b})$

$0.092 \mathrm{~m} \times 0.289 \mathrm{~m} \times 3.66 \mathrm{~m}(3.6 \mathrm{in} . \times 0.94 \mathrm{ft} \times 12 \mathrm{ft})$

$49.3 \mathrm{~m} / \mathrm{s}$ (161.7 ft/s) horizontal impact velocity

- 6-in. schedule 40 pipe

$130 \mathrm{~kg}(287 \mathrm{lb})$

$0.168 \mathrm{~m}$ diameter $\times 4.58 \mathrm{~m}$ (6.6 in. diameter $\times 15 \mathrm{ft}$ )

$8.2 \mathrm{~m} / \mathrm{s}(27.0 \mathrm{ft} / \mathrm{s})$ horizontal impact velocity 
- 1 -in. steel rod

$4 \mathrm{~kg}(8.8 \mathrm{lb})$

$0.0254 \mathrm{~m}$ diameter $\times 0.915 \mathrm{~m}$ ( 1 in. diameter $\times 3 \mathrm{ft}$ )

$7.6 \mathrm{~m} / \mathrm{s}(24.9 \mathrm{ft} / \mathrm{s})$ horizontal impact velocity

- Utility pole

$510 \mathrm{~kg}(1,124 \mathrm{lb})$

$0.343 \mathrm{~m}$ diameter $\times 10.68 \mathrm{~m}(13.5 \mathrm{in}$. diameter $\times 35 \mathrm{ft})$

$9.4 \mathrm{~m} / \mathrm{s}(30.7 \mathrm{ft} / \mathrm{s})$ horizontal impact velocity

- 12-in. schedule 40 pipe

$340 \mathrm{~kg}(750 \mathrm{lb})$

$0.32 \mathrm{~m}$ diameter $\times 4.58 \mathrm{~m}$ (12.75 in. diameter $\times 15 \mathrm{ft})$

$6.6 \mathrm{~m} / \mathrm{s}(21.8 \mathrm{ft} / \mathrm{s})$ horizontal impact velocity

- Automobile

$1810 \mathrm{~kg}(3,9901 \mathrm{~b})$

$5 \mathrm{~m} \times 2 \mathrm{~m} \times 1.3 \mathrm{~m}(16.4 \mathrm{ft} \times 6.6 \mathrm{ft} \times 4.3 \mathrm{ft})$

$32.1 \mathrm{~m} / \mathrm{s}(105.2 \mathrm{ft} / \mathrm{s})$ horizontal impact velocity.

The missiles are considered to strike surfaces in any direction, and the vertical velocities are $70 \%$ of the horizontal velocities except for the l-in. steel rod, which has the same velocity in any direction. The utility pole and automobile are considered to strike surfaces up to a maximum of $9.1 \mathrm{~m}(30 \mathrm{ft})$ above the highest finished grade within $0.8 \mathrm{~km}(0.5 \mathrm{mi})$ of the plant. The other missiles can strike at any elevation.

An alternative set of CSB design missiles that may be applied to the CSB has been developed for the $322 \mathrm{~km} / \mathrm{h}(200 \mathrm{mi} / \mathrm{h})$ total wind speed (Fluor Daniel 1996). They are listed below.

$852.2 \mathrm{~kg}(115 \mathrm{lb}), 0.10 \mathrm{~m} \times 0.305 \mathrm{~m} \times 3.66 \mathrm{~m}(4 \mathrm{in} . \times 12 \mathrm{in} . \times 12 \mathrm{ft}$ ) wood plank, with a horizontal impact velocity of $51.0 \mathrm{~m} / \mathrm{s}(167 \mathrm{ft} / \mathrm{s})$ at elevations up to $61.0 \mathrm{~m}(200 \mathrm{ft})$, maximum vertical velocity determined by free-fall from $61.0 \mathrm{~m}(200 \mathrm{ft})$

$86.8 \mathrm{~kg}(15 \mathrm{lb}), 0.05 \mathrm{~m} \times 0.10 \mathrm{~m}$ ( 2 in. $\times 4$ in.) timber/wood plank moving at $67 \mathrm{~m} / \mathrm{s}(220 \mathrm{ft} / \mathrm{s})$ horizontal velocity at elevations up to $61.0 \mathrm{~m}(200 \mathrm{ft}), 44.7 \mathrm{~m} / \mathrm{s}(147 \mathrm{ft} / \mathrm{s})$ vertical velocjty

- $4.0 \mathrm{~kg}(8.8 \mathrm{lb}), 0.025 \mathrm{~m}$ (1 in.) diameter $\times 0.91 \mathrm{~m}(3 \mathrm{ft})$ long steel rod, with a maximum horizontal impact velocity of $6.0 \mathrm{~m} / \mathrm{s}$ $(19.7 \mathrm{ft} / \mathrm{s})$

- $34.0 \mathrm{~kg}(75 \mathrm{lb}), 0.076 \mathrm{~m}$ (3 in.) schedule 40 steel pipe, $3.05 \mathrm{~m}$ (10 ft) long, with a horizontal impact velocity of $33.5 \mathrm{~m} / \mathrm{s}$ $(110 \mathrm{ft} / \mathrm{s})$ at elevations up to $30.48 \mathrm{~m}(100 \mathrm{ft}), 22.4 \mathrm{~m} / \mathrm{s}$ $(73.5 \mathrm{ft} / \mathrm{s})$ vertical velocity

- A $1,361 \mathrm{~kg}(3,000 \mathrm{lb})$ automobile rolling and tumbling into the base of the structure at $11.2 \mathrm{~m} / \mathrm{s}(36.7 \mathrm{ft} / \mathrm{s})$. 
An alternative to providing tornado missile protection for all safetyclass and important-to-safety SSCS is to address the need for protection of specific targets on a risk assessment basis. By this process, an estimate is made of the probability that a tornado generated missile will strike a particular target and fail the target in such a way that unacceptable consequences result. For facilities with relative small targets areas, the risk assessment can simply investigate the probability that a missile strikes a target. If the probability obtained of the a missile striking and failing a target, or simply striking the target, satisfies established acceptance criteria, then no physical barriers against missiles need be provided.

The use of probabilistic risk assessment techniques to establish the need to provide tornado-generated missile protection for specific targets has been accepted by the NRC for several years and is well documented in their review and design guidance. For example, the NRC Standard Review Plan (NRC 1981), Section 3.5.1.5, "Site Proximity Missiles (Except Aircraft)," includes the following statement relative to low risk of exposure to the public.

This requirement is met if the probability of site proximity missiles impacting the plant and causing radiological consequences greater than 10 CFR Part 100 exposure guidelines is less than about $10^{-7}$ per year (see SRP Section 2.2.3).

The NRC Standard Review Plan (NRC 1981), Section 2.2.3, "Evaluation of Potential Accidents," accepts $10^{-6}$ events/yr for offsite hazards exceeding the guidelines in Title 10, Code of Federal Regulations, Part 100, "Reactor Site Criteria" (10 CFR 100), if, when accompanied with reasonable qualitative arguments, the realistic value can be shown to be lower. For the CSB, an acceptance criterion to not exceed the $5 \mathrm{rem}(50 \mathrm{mSv})$ ] imit of 10 CFR 72.106 at the controlled area boundary should be used.

The probability of a tornado occurring near the site and generating a missile that results in acceptable consequences can be expressed as follows:

$$
P_{T M}=P_{S} \times P_{m s} \times P_{F} \times P_{D}
$$

where

$P_{T M}=$ The annual probability of a tornado missile striking such that an unacceptable radiological or chemical release occurs

$P_{s}=$ The tornado annual point strike frequency (events/yr)

$P_{m s}=$ The probability of a tornado-generated missile impacting a specific target (this includes the probabilities of the missile existing on the site, being lifted, and striking the target of a given area)

$P_{F}=$ The probability of target failure as a result of being struck by a missile (this considers that not all missiles that strike the target will be of sufficient energy to fail the target) 

$P_{D}=$ The probability, given the failure of the target by a missile, that unacceptable radiological or chemical release occurs (this considers that not all target failures will be of sufficient severity to result in unacceptable consequences).

The above expression is simplified in that the analyses are usually performed for a range of tornado intensities and potential missiles. The tornado intensities considered are based upon available local severe weather data. The missiles considered vary in terms of their density on the site, ability to be lifted by a tornado of a given intensity, and ability to damage the target. The missiles appropriate for consideration are often established by a site survey for a radius of about $600 \mathrm{~m}(2,000 \mathrm{ft})$.

It should be noted in the above equation that the missile selection is based upon realistic selection of potential missiles based upon a site survey. It does not adopt the NRC tornado missile spectrum, which is more appropriate for an upper bound mechanistic analysis.

\subsection{VOLCANIC ASH CRITERIA}

\subsection{BACKGROUND}

Volcanic hazards that have affected the Hanford Site in the past 20 million years are of two types: (1) continental flood basalt volcanism that produced the Columbia River Basalt Group, which underlies the Hanford site, outcropping in the surrounding ridges; and (2) volcanism associated with the Cascade Range. Several volcanoes in the Cascade Range are currently considered to be active, but activity associated with flood basalt volcanism has ceased.

The flood basalt volcanism that produced the Columbia River Basalt Group occurred between 17 million and 6 million years before present (BP). Most of the lava was extruded during the first 2 to 2.5 million years of the 11-million-year volcanic episode. Volcanic activity has not recurred during the last 6 million years, suggesting cessation of the tectonic processes that created the episode. The recurrence of Columbia River basalt volcanism is not considered to be a credible volcanic hazard (DOE 1988).

Volcanism in the Cascade Range has been active throughout the Pleistocene Epoch (approximately 2 million years BP to 10,000 years $B P$ ), through the Holocene Epoch $(10,000$ years BP to present). The eruption history of the Holocene best characterizes the most likely types of activity in the next 100 years. Many of the volcanoes have been active in the 7 ast 10,000 years, including Mount Mazama (Crater Lake) and Mount Hood in Oregon, and Mount St. Helens, Mount Adams, and Mount Rainier in Washington. The Hanford Site is approximately $150 \mathrm{~km}$ (95 mi) from Mount Adams, $175 \mathrm{~km}$ (110 mi) from Mount Rainier and $200 \mathrm{~km}(125 \mathrm{mi})$ from Mount St. Helens, the three closest active volcanoes. At these distances, the tephra (ash) is the only hazard. Mount St. Helens has been considerably more active throughout the Holocene than Mount Rainier or Mount Adams, which is the least active of the three. The remainder of this discussion addresses the criteria for volcanic ash. 
Probabilistic volcanic hazard studies of the Cascade Range have been completed by the U.S. Geological Survey (Hoblitt et al. 1987;

Scott et a1. 1995). Figure 4 illustrates the annual probability of exceeding $1 \mathrm{~cm}(0.4 \mathrm{in}$.$) of volcanic ash accumulation in Washington and Oregon following$ the eruption of a major Cascade Range volcano, and Figure 5 illustrates the annual probability of exceeding $10 \mathrm{~cm}$ (4 in.) of volcanic ash accumulation. Figure 6 presents this information as a volcanic ash hazard curve for the Hanford Site.

\subsection{U.S. DEPARTMENT OF ENERGY DESIGN REQUIREMENTS}

DOE has no specific orders or standards setting design criteria for ash loads. Criteria for determining design basis ash loads were developed specifically for the Hanford Site (Salmon 1996) to ensure that the performance goals of DOE Order 5480.28 are met. The design basis ashfall loads and recommended risk reduction factors for the Hanford Site given in Table 2 are based on the hazard curve shown in Figure 6 . For Performance Categories 1, 2, and 3 , ashfall need not be considered because it is not a controlling load when using the load combinations for the design and analys is found in DOE-STD-1020-94.

Operations that require air filtration or heating, ventilation, or air conditioning throughout an ashfall event must take into account the impact of suspended ash on the operation. Unlike most other NPHs, some level of warning precedes volcanic hazards, especially distal ashfall. First, there is almost always increased seismic activity at the volcano from days to years before large eruptions. Further, heat gradients often increase, steam and smaller eruptions may be emitted from the volcano, and measurable deformation may occur on the volcano's surface. All these warnings provide a general alert and increase emergency preparedness in the immediate area of the volcano as well as downwind in an area like the Hanford Site. Second, it would take approximately 2 hours for ash from the closest active volcanoes to reach the Hanford Site (Scheidegger et a1. 1982). This shorter warning time is for the much higher probability that the ash will affect the Site. This warning may lend itself to administrative controls for ashfall mitigation. Administrative procedures implemented after an eruption should be used when mitigation can be achieved through evacuation; reconfiguration of the structure, system, or component; operation shutdown; or other activities appropriate for the specific facility or operation. Should it be determined that a safe configuration cannot be achieved during the 2-hour warning time preceding the ashfall, the appropriate suspended ash load will be determined.

\subsection{U.S. NUCLEAR REGULATORY COMMISSION DESIGN REQUIREMENTS}

There is no NRC design requirement or regulatory guide for volcanic hazards, namely ashfall. The Supply System's Hanford Site design basis for ashfall for safety-related SSCs is $117 \mathrm{~kg} / \mathrm{m}^{2}$ (24 $1 \mathrm{bs} / \mathrm{ft}^{2}$ ), which is $7.4 \mathrm{~cm}$ (3 in.) of compacted ash (NRC 1982) with a dry compacted density of $1,538 \mathrm{~kg} / \mathrm{m}^{3}\left(96 \mathrm{lb} / \mathrm{ft}^{3}\right)$. This Supply System ash load, which is larger than that of the DOE requirement, is applied to the CSB. The $7.4 \mathrm{~cm}(3 \mathrm{in}$. compacted ash will not interfere with the natural circulation heat removal vent in the CSB. Volcanic ash is considered an extreme environmental load and is not combined with other extreme environmental loads. 
Figure 4. Annual Probability of One Centimeter or More of Volcanic Ash Accumulation in Washington and Oregon from Major Cascade Volcanoes.
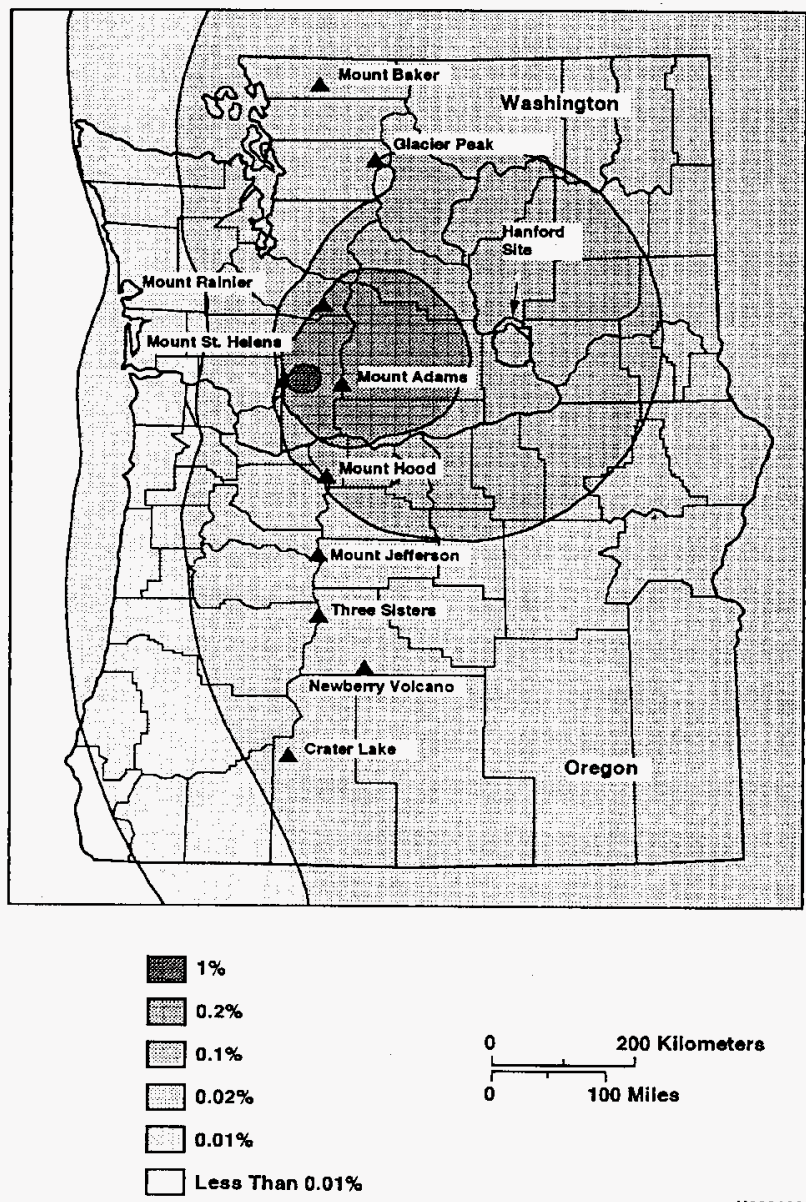
Figure 5. Annual Probability of Ten Centimeters or More of Volcanic Ash Accumulation in Washington and Oregon from Major Cascade Volcanoes.

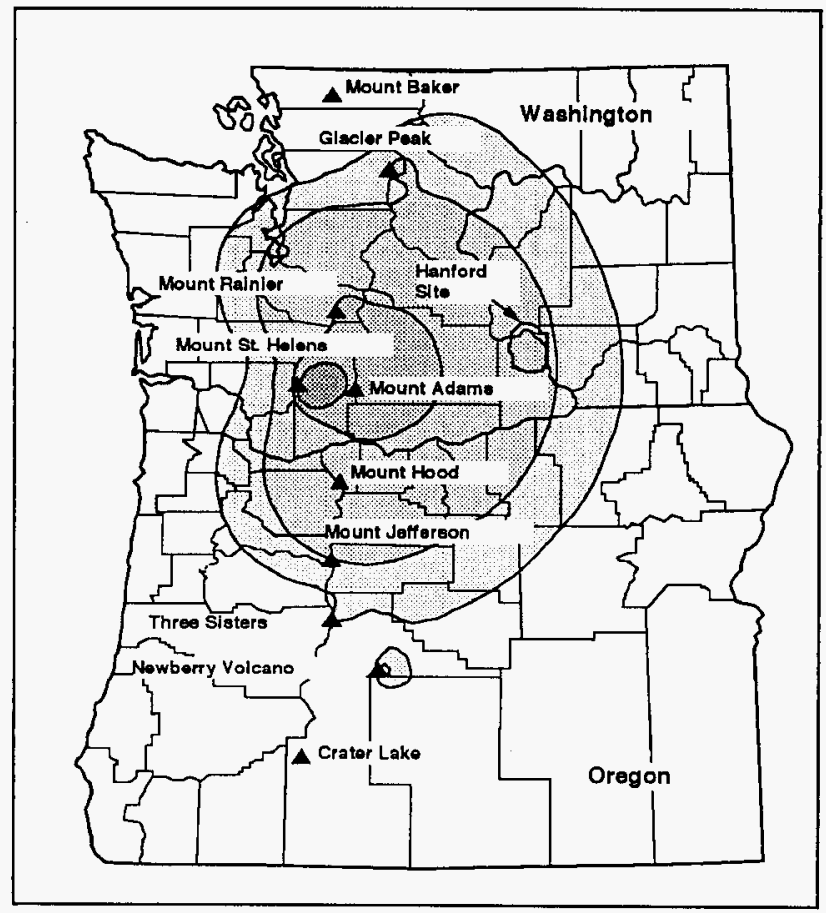

$1 \%$
$0.2 \%$
$0.1 \%$
$0.02 \%$
$0.01 \%$
$\square$ Less Than $0.01 \%$


WHC-SD-SNF-DB-009 REV 3

Figure 6. Cascade Range Volcanic Ash Hazard.

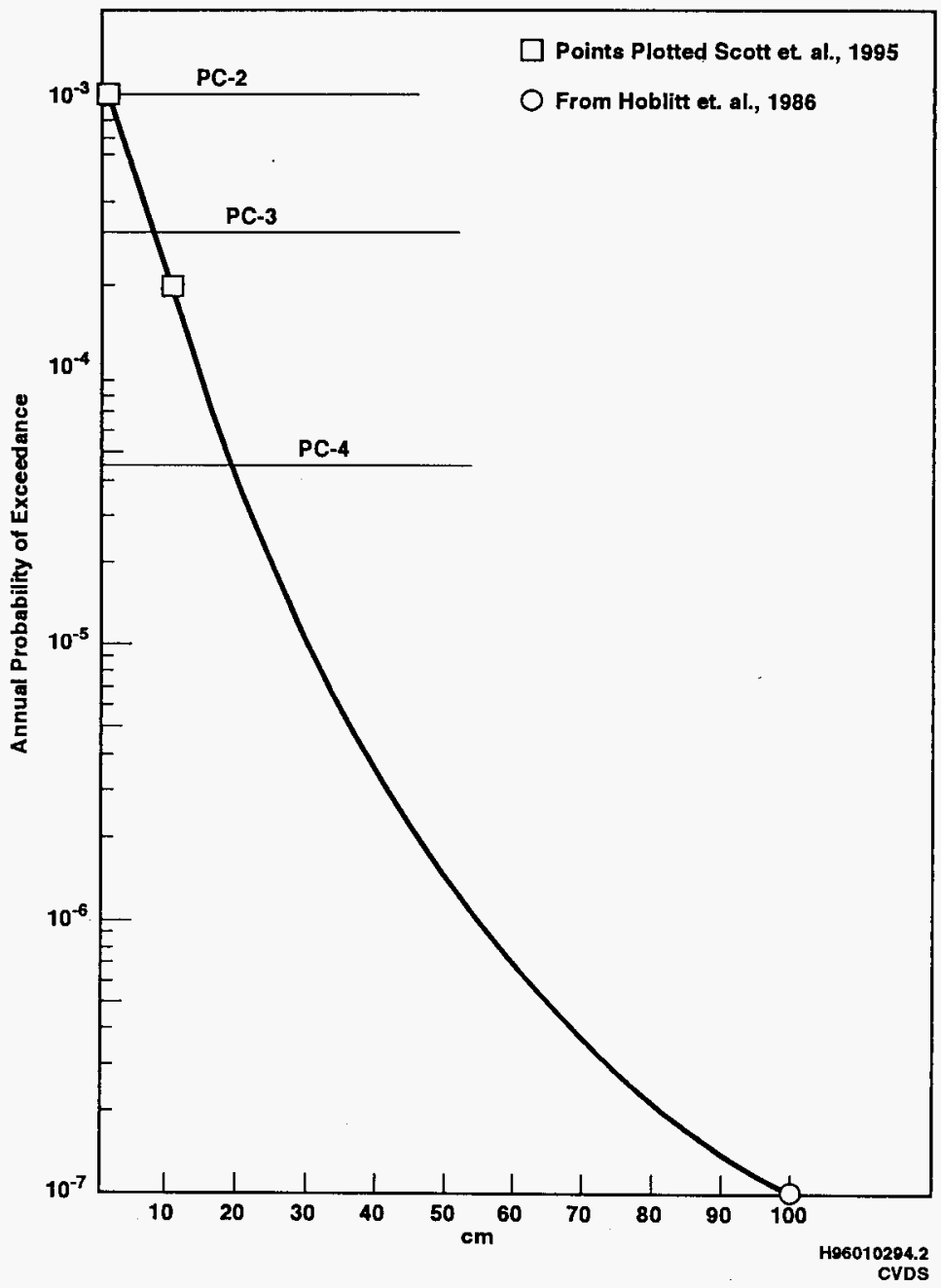


Table 2. Design Basis Loads for Ashfall Criteria.

\begin{tabular}{|c|c|c|c|c|c|}
\hline $\begin{array}{c}\text { Performance } \\
\text { Category }\end{array}$ & $\begin{array}{c}\text { performance goal } \\
\left(P_{Q}\right)\end{array}$ & $\begin{array}{c}\text { Hazard curve } \\
\text { slope parameter } \\
\left(A_{R}\right)\end{array}$ & $\begin{array}{c}\text { Risk reduetion } \\
\text { factor }\end{array}$ & $\begin{array}{c}\text { Ash hazard } \\
\text { probability } \\
\left(P_{n)}\right.\end{array}$ & $\begin{array}{c}\text { Design } \\
\text { ashfall } \begin{array}{c}\text { Joad } \\
\left(\mathrm{kg} / \mathrm{m}^{2}\right)\end{array}\end{array}$ \\
\hline 1 & $1 \times 10^{-3}$ & 5.0 & 2.1 & $2.1 \times 10^{-3}$ & $14.6 \mathrm{~kg} / \mathrm{m}^{2}$ \\
\hline 2 & $5 \times 10^{-4}$ & 5.0 & 2.1 & $1.05 \times 10^{-3}$ & $24.4 \mathrm{~kg} / \mathrm{m}^{2}$ \\
\hline 3 & $1 \times 10^{-4}$ & 3.1 & 3.0 & $3.0 \times 10^{-4}$ & $61 \mathrm{~kg} / \mathrm{m}^{2}$ \\
\hline 4 & $1 \times 10^{-5}$ & 2.0 & 4.3 & $4.3 \times 10^{-5}$ & $146.5 \mathrm{~kg} / \mathrm{m}^{2}$ \\
\hline
\end{tabular}

Note: Information in this table is from Salmon, M., 1996, Volcanic Ashfall Loods for the Hanford Site, WHC-SD-GN-ER-30038, Rev. D, West inghouse Hanford Company, Richland, Washington.

Operations that require air filtration or heating, ventilation, or air conditioning throughout an ashfall event must take into account the impact of suspended ash on the operation.

\subsection{FLOOD CRITERIA}

\subsection{BACKGROUND}

The CSB site is at an elevation of about $213 \mathrm{~m}(700 \mathrm{ft})$ above mean sea level. The Columbia River is closest to the CSB at river kilometer 595 (mile 370 ) where the normal flow is at approximately $115 \mathrm{~m}$ (375 ft) above mean sea level. At the same river kilometer, the estimated flood level at a mean annual probability of $1 \times 10^{-4}$ (the annual probability of exceedance for Performance Category 3 design) is $133 \mathrm{~m}(435 \mathrm{ft}$ ) above mean sea level (McCann and Boissonnade 1988). This is about $80 \mathrm{~m}(265 \mathrm{ft})$ below the CSB. The CSB is also about $78 \mathrm{~m}$ (250 ft) above the Grand Coulee Dam failure flood (BOR 1982). Cold Creek and Dry Creek are ephemeral streams on the western portion of the Hanford Site. These streams are not of concern for the CSB site as they are in the Yakima River drainage basin and the CSB is in the Columbia River drainage basin. The probable maximum flood is approximately $30 \mathrm{~m}$ (100 ft) below the elevation of the divide between the Columbia River and the Yakima River (Skaggs and Walters 1981). The CSB site is a flood-dry site with respect to river flooding, so only flooding caused by precipitation runoff need be considered.

\subsection{U.S. DEPARTMENT OF ENERGY DESIGN REQUIREMENTS}

DOE guidance in DOE-STD-1020-94 states that the performance goals for SSCs must be satisfied when subjected to the design basis flood level for local precipitation. This can be done through design features to provide sufficient runoff capacity and through facility strengthening. The performance goal is $1 \times 10^{-4}$ for a Performance Category 3 structure such as the CSB. The probable maximum precipitation (PMP) is conservatively assumed to have an annual probability of exceedance of less than $1 \times 10^{-6}$ (ASCE 1988). 
The NRC requirement is the PMP, which is a lower probability storm and higher precipitation value than the DOE requirement.

\subsection{U.S. NUCLEAR REGULATORY COMMISSION DESIGN REQUIREMENTS}

NRC guidance in 10 CFR 72 says that "the facility must be sited so as to avoid to the extent possible the long-term and short-term adverse impacts associated with the occupancy and modification of floodplains." No guidance is given for the probabilities of flooding or precipitation to be addressed. The 24-hour PMP estimates are recommended for use in constructing runoff models for nuclear power reactors to estimate the discharge to the site's storm drainage system (NRC 1981, ANSI/ANS 1992).

A recent cooperative study by the National Oceanic and Atmospheric Administration, the Bureau of Reclamation, and the Corps of Engineers has updated the PMP estimates for the Pacific Northwest (Hansen et al. 1994). This document supersedes other earlier work done by these organizations and is the source used for the PMP shown in Table 3. The PMP values are estimates of the maximum precipitation physically possible for both general storms (large air mass interactions) and local storms (unstable air, thunderstorms). At the Hanford Site the 6-hour local storm produces more precipitation than the 24-hour general storm. No annual probability of exceedance is given in Hydrometeorological Report No. 57, Probable Maximum Precipitation-Pacific Northwest States (Hansen et al. 1994), for the PMP for either general or local storms. The PMP is conservatively assumed to have an annual probability of exceedance of $1 \times 10^{-6}$ or less (ASCE 1988). If the 6-hour local storm has an annual probability of $1 \times 10^{-6}$, the PMP values for an annual probability of $1 \times 10^{-4}$ are estimated on limited data to be approximately $13 \mathrm{~cm}(5 \mathrm{in}$.) when considering a $1-\mathrm{mi}^{2}$ area and approximately $9 \mathrm{~cm}(3.5 \mathrm{in.})$ when considering a $10-\mathrm{mi}^{2}$ area.

At the Hanford Site, using the PMP for the local storm is more conservative than using the PMP for the general storm, which occurs over a larger area. The PMP for a local $1-\mathrm{mi}^{2}, 6$-hour storm $(23.4 \mathrm{~cm}[9.2 \mathrm{in.}])$ will be used for the CSB design (Table 3). The slightly lower $10-\mathrm{mi}^{2}$ rate (18.8 cm [7.4 in.] in 6 hours) will be used for calculating the surrounding watershed runoff.

\subsection{LIGHTNING}

Neither DOE nor NRC have developed specific requirements for dealing with lightning. NFPA 780, Lightning Protection (NFPA 1992), is recommended as guidance by DOE and NRC and will be applied for lightning protection for the CSB. 
Table 3. Extreme Precipitation Estimates for the Hanford Site.

\begin{tabular}{|c|c|c|c|c|c|c|}
\hline Time & $\begin{array}{c}\text { PMP 24-hour } \\
\text { general } \\
\text { storm } \\
\left(10 \mathrm{mi}^{2}\right)^{a}\end{array}$ & $\begin{array}{l}\text { PMP local } \\
\text { storm } \\
\left(1 \mathrm{mi}^{2}\right)^{a}\end{array}$ & $\begin{array}{l}\text { PMP local } \\
\text { storm } \\
\left(10 \mathrm{mi}^{2}\right)^{\mathrm{B}}\end{array}$ & $\begin{array}{l}25-\text { year } \\
\text { average } \\
\text { return } \\
\text { period }^{b}\end{array}$ & $\begin{array}{l}\text { 100-year } \\
\text { average } \\
\text { return } \\
\text { period }\end{array}$ & $\begin{array}{l}\text { 1,000-year } \\
\text { average } \\
\text { return } \\
\text { period }^{b}\end{array}$ \\
\hline 15 minutes & -- & 4.0 & 3.2 & -- & -- & -- \\
\hline 20 minutes & -- & -- & - & 0.47 & 0.60 & 0.80 \\
\hline 30 minutes & -- & 6.0 & 4.8 & $\ldots$ & -- & -- \\
\hline 45 minutes & - & 7.2 & 5.8 & -- & -- & - \\
\hline 1 hour & 1.6 & 8.0 & 6.4 & 0.62 & 0.81 & 1.11 \\
\hline 6 hours & 4.7 & 9.2 & 7.4 & 1.21 & 1.59 & 2.20 \\
\hline 24 hours & 8.0 & -- & - & 1.56 & 1.99 & 2.68 \\
\hline 48 hours & 9.6 & -- & -+ & -- & -- & -- \\
\hline 72 hours & 10.4 & -- & -- & -- & -- & -- \\
\hline
\end{tabular}

Notes: Precipitation depths are in inches. To convert to centimeters, multiply by 2.54 .

AHansen, E. M., D. D. Fenn, P. Corrigan, J. L. Vogel, L. C. Schreiner, and R. W. Stodt, 1994, Probable Maximum Precipitation - Pacific Northwest States, Hydrometeorological Report No. 57, Mational Weather Service, Silver Spring, Maryland.

Stone, W. A., J. M. Thorp, O. P. Gifford, and D. J. Hoitink, 1983, climatological Summary for the Hanford Site, PNL-4622, Pacific Nor thwest Laboratory, Richland, Washington.

PMP = probable maximum precipitation. 


\subsection{SNOW LOAD}

Both DOE and NRC recommend following ASCE-7-93 (ASCE 1993) for ground snow loads and design guidance. The Supply System's ground snow Toad of $98 \mathrm{~kg} / \mathrm{m}^{2}\left(20 \mathrm{lb} / \mathrm{ft}^{2}\right)$ is applied to the CSB.

\subsection{REFERENCES}

10 CFR 72, "Licensing Requirements for the Independent Storage of Spent Nuclear fuel and High-Level Radioactive Waste," Code of Federal Regulations, as amended.

10 CFR 100, "Reactor Site Criteria," Code of Federal Regulations, as amended.

ANSI/ANS, 1992, Determining Design Basis Flooding at Power Reactor Sites, ANSI/ANS-2.8-1992, American Nuclear Society, La Grange Park, Illinois.

ASCE, 1961, "Wind Forces on Structures," Transaction of the American Society of Civil Engineers, Vol. 126, Part II, American Socjety of Civil Engineers, Washington, D.C.

ASCE, 1988, Evaluation Procedures for Hydrologic Safety of Dams, American Society of Civil Engineers, New York, New York.

ASCE, 1993, Minimum Design Loads for Building and Other Structures, ASCE-7-93, American Society of Civil Engineers, New York, New York.

BOR, 1982, Emergency Preparedness Brief with Inundation Map from Standing Operating Procedures, Grand Coulee Dam, Bureau of Reclamation, U.S. Department of the Interior, Washington, D.C.

Clifford, J. W., 1996, Revision of Tornado Design Criteria for the Washington Public Power Supply System (WPPSS) Nuclear Project No. 2 (TAC No. 88626) (letter GI2-96-032 to J. V. Parrish, Washington Public Power Supply System, January 24), U.S. Nuclear Regulatory Commission, Washington, D.C.

Coats, D. W. and R. C. Murray, 1985, Natural Phenomena Hazards Modeling Project: Extreme Wind/Tornado Hazard Models for Department of Energy Sites, UCRL-53526, Rev. 1, Lawrence Livermore National Laboratory, Livermore, California.

DOE, 1988, Site Characterization Plan, Consultation Draft, DOE/RW/0164, Vol. 1, U.S. Department of Energy, Washington, D.C.

DOE Order 5480.28, Natural Phenomena Hazards Mitigation, U.S. Department of Energy, Washington, D.C.

DOE-STD-1020-94, 1994, Natura7 Phenomena Hazards Design and Evaluation Criteria for Department of Energy Facilities, U.S. Department of Energy, Washington, DC. 
DOE-STD-1022-94, 1994, Natura7 Phenomena Hazards Site Characteristics Criteria, U.S. Department of Energy, Washington, D.C.

DOE-STD-1023-95, 1995, Natural Phenomena Hazards Assessment Criteria, U.S. Department of Energy, Washington, D.C.

Fluor Daniel, 1996, SNF CSB - Tornado Strategy Implementation Plan and Probabilistic Risk Analysis (Letter FRF-2834 Rl to M. K. Mahaffey, Westinghouse Hanford Company, July 18), Fluor Daniel, Incorporated, Richland, Washington.

Geomatrix, 1996, Probabilistic Seismic Hazard Analysis, DOE Hanford Site, Washington, WHC-SO-W236A-TI-002, Rev. 1, prepared by Geomatrix Consultants, Incorporated, for Westinghouse Hanford Company, Richland, Washington.

Hansen, E. M., D. D. Fenn, P. Corrigan, J. L. Vogel, L. C. Schreiner, and R. W. Stodt, 1994, Probable Maximum Precipitation-Pacific Northwest States, Hydrometeorological Report No. 57, National Weather Service, Silver Spring, Maryland.

Hoblitt, R. P., C. D. Miller, and W. E. Scott, 1987, Volcanic Hazards with Regard to Siting Nuclear-Power Plants in the Pacific Northwest, Open-File Report 87-297, U.S. Geological Survey, Cascades Volcano Observatory, Vancouver, Washington.

Hoitink, D. J., and K. W. Burk, 1994, Hanford Site Climatological Data Summary 1993 with Historical Data, PNL-9809, Pacific Northwest Laboratory, Richland, Washington.

ICBO, 1994, Uniform Building Code, International Conference of Building officials, Whittier, California.

McCann, M. W. Jr., and A. C. Boissonnade, 1988, Probabilistic Flood Hazard Assessment for the N-Reactor, Hanford, Washington, UCRL-21069, Lawrence Livermore National Laboratory, Livermore, California.

Newmark, N. M., and W. J. Hall, 1978, Development of Criteria for Seismic Review of Selected Nuclear Power Plants, NUREG/CR-0098, U.S. Nuclear Regulatory Commission, Washington, D.C.

NFPA, 1992, Lightning Protection, NFPA 780, National Fire Protection Association, Quincy, Massachusetts.

NRC, 1974, Design Basis Tornado for Nuclear Power Plants, Regulatory Guide 1.76, U.S. Nuclear Regulatory Commission, Washington, D.C.

NRC, 1981, Standard Review Plan, NUREG-0800, U.S. Nuclear Regulatory Commission, Washington, D.C.

NRC, 1982, Safety Evaluation Report Related to the Operation of WPPSS Nuclear Project No. 2, NUREG-0892, Supplement No. 1, U.S. Nuclear Regulatory Commission, Washington D.C. 
NRC, 1993, Policy, Technical, and Licensing Issues Pertaining to Evolutionary and Advanced Light-Water Reactor (ALWR) Designs, SECY-93-087, U.S. Nuclear Regulatory Commission, Washington, D.C.

NRC, 1994, Final Safety Evaluation Report Related to the Certification of the Advanced Boiling Water Reactor Design, NUREG-1503, U.S. Nuclear Regulatory Commission, Washington, D. C.

Parrish, J. V., 1995, WNP-2, Operating License NPF-21, Request for Approval to Revise Tornado Design Criteria. (Tetter G02-95-212 to U.S. Nuclear Regulatory Commission, October 10), Washington Public Power Supply System, Richland, Washington.

Ramsde11, J. V., and G. L. Andrews, 1986, Tornado Climatology of the Contiguous United States, NUREG/CR-4461, prepared for the U.S. Nuclear Regulatory Commission by Pacific Northwest Laboratory, Richland, Washington.

Ramsde11, J. V., C. G. Elliott, C. G. Holladay, and J. M. Hubbe, 1986, Methodology for Estimating Extreme Winds for Probabilistic Risk Assessments, NUREG/CR-4492, Prepared for the U.S. Nuclear Regulatory Commission by Pacific Northwest Laboratory, Richland, Washington.

Salmon, M., 1996, Volcanic Ashfall Loads for the Hanford Site, WHC-SD-GN-ER-30038, Rev. 0, Westinghouse Hanford Company, Richland, Washington.

Scheidegger, K. F., A. N. Federman, A. M. Tallman, 1982, "Compositional Heterogeneity of Tephras from the 1980 Eruptions of Mount St. Helens," Journal of Geophysical Research, Vol. 87, pp 10,861-10,881.

Scott, W. E., R. Iverson, M. Vallance, W. James, and W. Hildreth, 1995, Volcano Hazards in the Mount Adams Region, Washington, Open-File Report 95-492, U.S. Geological Survey, Washington, D.C.

Skaggs, R. L., and W. H. Walters, 1981, Flood Risk Analysis of Cold Creek Near the Hanford Site, RHO-BWI-C-120, prepared by Pacific Northwest Laboratory for Rockwell Hanford Operations, Richland, Washington.

Stone, W. A., J. M. Thorp, O. P. Gifford, and D. J. Hoitink, 1983, Climatological Summary for the Hanford Site, PNL-4622, Pacific Northwest Laboratory, Richland, Washington.

WHC, 1992, Hanford Waste Vitrification Plant Preliminary Safety Analysis Report, WHC-SD-HWV-PSAR-001, Rev. 0, Westinghouse Hanford Company, Richland, Washington.

WHC, 1996, Spent Nuclear Fuel Project Seismic Design Criteria, WHC-SD-SNF-DB-004, Rev. 2, Westinghouse Hanford Company, Richland, Washington. 
WHC-SD-SNF-DB-009 REV 3

This page intentionally left blank. 
WHC-SD-SNF-DB-009 REV 3

\section{APPENDIX A}

WNP-2, OPERATING LICENSE NPF-21, REQUEST FOR APPROVAL

TO REVISE TORNADO DESIGN CRITERIA

A-1 
WHC-SD-SNF-DB-009 REV 3

This page intentionally left blank. 
October 10, 1995

GO2-95-212

Docket No. 50-397

U.S. Nuclear Regulatory Commission

Attn: Document Control Desk

Washington, D.C. 20555

Gentlemen:

Subject: WNP-2, OPERATTNG LICENSE NPF-21

REQUEST FOR APPROVAL TO REVISE TORYADO DESIGN CRITERIA

References: 1) Letter G02-91-116, dated June 7, 1991, GC Sorensen (SS) to NRC, same subject

2) Letter G02-94-001, dated January 6, 1994, JV Parrish (SS) to NRC, same subject

3) Final Safety Evaluation Report Related to the Certification of the Advanced Boiling Water Reactor Design, NUREG-1503, July 1994

4) NUREG-0892, Safety Evaluation Report Related to the Operation of WPPSS Nuclear Project No.2, March 1982

5) NUREG-0800, Standard Review Plan, June 1987

6) Regulatory Guide 1.76, April-1974, Design Basis Tornado for Nuclear Power Plants.

By References 1 and 2, in accordance with the guidance of Reference 6, Section C. 2, the Supply System requested approval to revise the WNP-2 tomado design criteria. Reference 1 requested that the total design basis tomado wind speed for WNP-2 be revised to $180 \mathrm{mph}$. Based on discussions with the staff, the Supply System revised its request via Reference 2 to set the tomado design basis wind speed to $192 \mathrm{mph}$. Although the Supply System feels that each of these submittals is technically justified, the Supply System is hereby further revising its request to establish the total design basis wind speed to $200 \mathrm{mph}$. The current request is based on furcher discussions with the staff and is consistent with the design basis tomado characteristics accepted by the NRC in Reference 3 for the tomado intensity region containing WNP-2. The complete definition of the proposed design basis tomado characteristics including the proposed design basis missiles are provided in the attachment. 
Page 2

REQUEST FOR APPROVAL TO REVISE TORNADO DESIGN CRTTERIA

Should you have any questions or desire additional information regarding this marter, please call me or D. A. Swank at (509) 377-4563.

\section{Sincerely,}

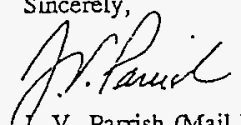

U. V. Parrish (Mail Drop 1023)

Vice President, Nuclear Operations

WLU/REB/ml

Attachment

cc: LJ Callan - NRC RTV

KE Perkins, Jr. - NRC RTV, Walnut Creek Field Office

NS Reynolds - Winston \& Strawn

SW Clifford - NRC

DL Williams - BPA 399

NRC Sr. Resident Inspector - $927 \mathrm{~N}$ 
WNP-2 current tomado design criteria, as stated in WNP-2 FSAR Sections 2.3.1.2.1.3 and 3.3.2.1, are for wind speeds of $300 \mathrm{mph}$ rotational and $60 \mathrm{mph}$ translational, with a pressure drop of 3 psi to occur in 3 seconds. These criteria were found acceptable by the staff as documented in Reference 4, Section 3.3.2. The Supply System proposes to change the design. criteria to 160 and $40 \mathrm{mph}$ rotational and translational velocities with a pressure drop of 0.90 psi occurring at $0.30 \mathrm{psi} / \mathrm{sec}$.

Relative to the requirements of Reference 6 , the curreat design requirements are conservative in that WNP-2 is a Region III site for which the criteria are $190 \mathrm{mph}$ rotational and $50 \mathrm{mph}$ translational with a 1.5 psi pressure drop at $0.6 \mathrm{psi} / \mathrm{sec}$. WNP-2 FSAR Section 3.3.2.4 and Appendix C.3 discuss the WNP-2 design relative to Reference 6 . It is apparent that the currently proposed criteria are less than those proposed by the Regulatory Guide for a Region III plant.

WNP-2 FSAR Section 3.5.1.4 establishes the following design basis tornado generated missiles:

\begin{tabular}{|c|c|c|c|}
\hline Missile & $\begin{array}{c}\text { Weight } \\
\text { (lbs) }\end{array}$ & Dimensions & $\begin{array}{c}\text { Horizontal } \\
\text { Impact Velocity } \\
\text { (ft/sec) }\end{array}$ \\
\hline Utility Pole & 1600 & $14^{\prime \prime}$ dia $\times 35^{\prime}$ & 241 \\
\hline Steel Rod & 8 & $1^{\prime \prime}$ dia $\times 3^{\prime}$ & 259 \\
\hline
\end{tabular}

The NRC found these missiles acceptable in Section 3.5.1.4 of Reference 4.

Based upon the guidance of Reference 6, NRC approval of the use of revised tornado design criteria is requested. The criteria are:

Wind Speeds:

$200 \mathrm{mph}$ maximum

$160 \mathrm{mph}$ rotacional

40 mph translational

Pressure Drop:

$0.90 \mathrm{psi}$

at $0.30 \mathrm{psi} / \mathrm{sec}$ 
Missiles:

\begin{tabular}{|c|c|c|c|}
\hline Missile & $\begin{array}{c}\text { Weight } \\
\text { (lbs) }\end{array}$ & Dimensions & $\begin{array}{c}\text { Horizontal } \\
\text { Impact } \\
\text { Velocity } \\
\text { (ft/sec) }\end{array}$ \\
\hline \hline Wood Plank & 115 & $3.6^{\prime \prime} \times 0.94^{\prime} \times$ ' $2^{\prime}$ long & 161.7 \\
\hline $6^{\prime \prime}$ Sch 40 Pipe & 287 & $6.6^{\prime \prime} \mathrm{dia} \times 15^{\prime}$ long & 27.0 \\
\hline 1" Steel Rod & 8.8 & $1^{\prime \prime} \mathrm{dia} \times 3^{\prime}$ long & 24.9 \\
\hline Utility Pole & 1124 & $13.5^{\prime \prime} \mathrm{dia} \times 35^{\prime}$ long & 30.7 \\
\hline 12" Sch 40 & 750 & $12.75^{\prime \prime} \mathrm{dia} \times 15^{\prime}$ long & 21.8 \\
\hline Pipe & 3990 & $16.4^{\prime} \times 6.6^{\prime} \times 4.3^{\prime}$ & 105.2 \\
\hline Automobile & & & \\
\hline
\end{tabular}

Consistent with Reference 5, Section 3.5.1.4, these missiles are considered to strike surfaces in any direction. Vertical velocities are taken to be 70 percent of the horizontal velocities except for the 1 " steel rod which is assumed to have the same velocity in any direction. The utility pole and the automobile are considered to strike surfaces at any elevation up to a maximum elevation of 30 feet above the highest finished grade within 0.5 miles of the plant. The other missiles are considered to strike at any elevation.

Based on Reference 5, Section 3.3.2, total tomado loads resulting from wind loads, differential pressure loads, and tornado generated missiles will be established from the following equations:

$$
\begin{aligned}
& W^{\prime}=W_{w} \\
& W^{\prime}=W_{p} \\
& W^{\prime}=W_{m} \\
& W^{\prime}=W_{w}+0.5 W_{p} \\
& W^{\prime}=W_{w}+W_{m} \\
& W^{\prime}=W_{w}+0.5 W_{p}+W_{m}
\end{aligned}
$$

where:

$$
\begin{aligned}
& W^{\prime} \quad=\text { Total tornado load } \\
& W_{w} \quad=\text { Tornado wind load } \\
& W_{p} \quad=\text { Tomado differential pressure load } \\
& W_{m} \quad=\text { Tornado generated missile load }
\end{aligned}
$$


The above wind speed and pressure drop parameters are consistent with those values approved by the NRC for the Advanced Boiling Water Reactor Design for Tomado Intensity in Region III as defined in Section 2.0 of Reference 3. Based on the extensive studies which define site specific tornado hazards for the Hanford area, these wind speed and pressure drop parameters are conservative for the WNP-2 site. These studies are discussed in detail in the report attached to Reference 2.

In addition, the Supply System is proposing that the missiles to be considered consist of the full spectrum of missiles contained in Reference 5, Section 3.5.1.4. For those missiles, the proposed velocities are based on the above wind speed and pressure drop parameters. These missile velocities were developed by the Supply System using a methodology that we feel is consistent with that used to develop the SRP missile velocities. The Supply System will formalize the calculations associated with the development of these missile velocities after NRC has concurred with the proposed revised tomado design criteria, but prior to use in design work.

By implementing the proposed revisions, the tomado design criteria will conservatively reflect the tomado hazards at WNP-2 while maintaining the objective of providing an annual probability of exceedance of design loads of less than or equal to $1 \times 10^{7}$. These revisions will result in more realistic wind velocities, differential pressure loads, missile velocities, and load combinations. The proposed revisions will benefit the design of exterior structures and components that must consider postulated tornado effects. Significant benefit is expected during the implementation of future plant modifications where the revised tomado design criteria will facilitate construction. An example of this application is the Supply System's current effort to procure and install a dry cask spent fuel storage facility. 
WHC-SD-SNF-DB-009 REV 3

This page intentionally left blank. 
WHC-SD-SNF-DB-009 REV 3

\section{APPENDIX B}

REVISION OF TORNADO DESIGN CRITERIA FOR THE WASHINGTON PUBLIC POWER SUPPLY SYSTEM (WPPSS)

NUCLEAR PROJECT NO. 2 (WNP-2) 
WHC-SD-SNF-DB-009 REV 3

This page intentionally left blank. 

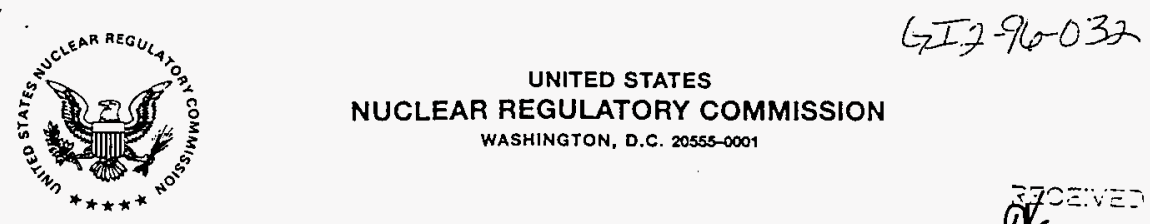

\section{UNITED STATES \\ NUCLEAR REGULATORY COMMISSION \\ WASHINGTON, D.C. 20555-0001}

January 24, 1996

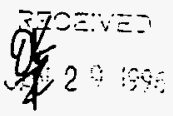

Mr. J. V. Parrish (Mail Drop 1023)

Vice President Nuclear Operations

3000 George Washington Way

Washington Public Power Supply System

P.0. Box 968

Richland, Washington 99352-0968

SUBJECT: REVISION OF TORNADO DESIGN CRITERIA FOR THE WASHINGTON PUBLIC

POLER SUPPLY SYSTEM (WPPSS) NUCLEAR PROJECT NO. 2 (WNP-2)

(TAC NO. M88626)

Dear Mr. Parrish:

By letter dated January 6, 1994, as modified by letter dated October 10, 1995, you requested staff review and approval of a proposed revision to the tornado design criteria for WNP-2. Our review is documented in the enclosed safety evaluation. We have determined that your proposed changes to the design tornado wind speeds and missile spectrum are acceptable.

This completes our work on TAC No. M88626. Please contact me at 301-415-1352 if you have any questions.

Sincerely,

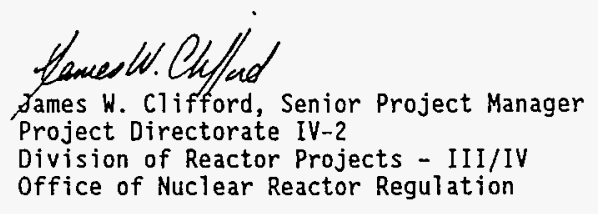

Docket No. 50-397

Enclosure: Safety Evaluation

cc w/enclosure:

See next page 
CC w/encl:

Mr. G. 0. Smith

WNP-2 Plant General Manager

Washington Public Power Supply System

P. 0. Box 968

Richland, Washington 99352-0968

Chief Counsel (Mail Drop 396)

Washington Public Power Supply System

P.0. Box 968

Richland, Washington 99352-0968

Mr. Frederick S. Adair, Chairman

Energy Facijity Site Evaluation Council

P. 0. Box 43172

Olympia, Washington 98504-3172

Mr. D. A. Swank (Mail Drop PE20)

WNP-2 Licensing Manager

Washington Public Power Supply System

P.0. Box 968

Richland, Washington 99352-0968

Mr. Paul R. Bemis (Mail Drop PE20)

Director, Regulatory and Industry Affairs

Washington Public Power Supply System

P.0. Box 968

Richland, Washington 99352

Regional Administrator, Region IV

U.S. Nuclear Regulatory Commission

Harris Tower \& Pavilion

611 Ryan Plaza Drive, Suite 400

Arlington, Texas 76011-8064

Chairman

Benton County Board of Commissioners

P.0. Box 69

Prosser, Washington 99350-0190

Mr. R. C. Barr, Senior Resident Inspector

U.S. Nuclear Regulatory Commission

P.0. Box 69

Richland, Washington 99352-0968

M. H. Philips, Jr., Esq.

Winston \& Strawn

1400 L Street, N.W.

Washington, OC 20005-3502 


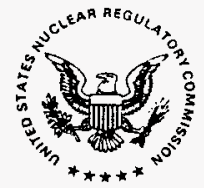

\author{
WHC-SD-SNF-DB-009 REV 3 \\ UNITED STATES \\ NUCLEAR REGULATORY COMMISSION \\ WASHINGTON, D.C. 20555-001
}

SAFETY EVALUATION BY THE OFFICE OF NUCLEAR REACTOR REGULATION

RELATED TO REVISED TORNADO DESIGN CRITERIA

WASHINGTON PUBLIC POWER SUPPLY SYSTEM

NUCLEAR PROJECT NO. 2

DOCKET NO. $50-397$

\title{
1.0 INTRODUCIION
}

By letter dated January 6, 1994, the Washington Public Power Supply System (the Supply System or the Ticensee) requested the staff's approval to revise the tornado design criteria for the WPPSS Nuclear Project No. 2, (WNP-2). By letter dated July 13, 1995, the staff requested additional justification for the licensee's proposed maximum composite wind speed of $192 \mathrm{mph}$. By letter dated October 10, 1995, the Supply System modified their propased maximum composite wind speed to $200 \mathrm{mph}$ and provided supporting justification. The current licensing basis tornado design criteria for WNP-2 are wind speeds of 300 miles per hour (mph) rotational and $60 \mathrm{mph}$ translational. The proposed change, as requested in the 0ctober 10, 1995 submittal, would revise the criteria to establish the total design basis tornado wind speed at $200 \mathrm{mph}$ (160 mph rotational and $40 \mathrm{mph}$ transiational). The request is based on the design basis tornado characteristics (for the tornado intensity region in which WNP-2 is located) accepted by the staff in NUREG-1503, "Final Safety Evaluation Report Related to the Certification of the Advanced Boiling Water Reactor Design," July 1994.

\subsection{EVALUATION}

The current licensing basis tornado design criteria for WNP-2 are based on a tornado Region I plant site as defined in Regulatory Guide (RG) 1.76, "Design Basis Tornaujo cor Nuclear Fower Piants." These are excessive criteria for WNP-2 because it is located in a tornado Region III as defined in RG 1.76 . The licensee's proposed tornado wind speed is also less than the wind speed identified in RG 1.76 for a design basis Region III tornado. This further reduction in tornado design criteria is consistent with the design basis characteristics accepted by the staff in NUREG-1503. Tabie 2-1 of NUREG-1503 establishes revised design basis tornado characteristics that are acceptable to the staff. The licensee's proposed revision is consistent with that table.

In NUREG-1503, the staff refers to SECY-93-087, "Policy, Technical, and Licensing Issues Pertaining to Evoiutionary and Advanced Light-Water Reactor (ALWR) Designs," dated Apri7 2, 1993, as a basis for revised tornado wind speeds. As described in SECY-93-087, the staff reevaluated the regulatory positions in RG 1.76 using the considerable quantity of tornado data which has become available since RG 1.76 was developed. This reevaluation is discussed 
WHC-SD-SNF-DB-009 REV 3

in NUREG/CR-4661, "Tornado Climatology of the Contiguous United States," dated May 1986. Based on the updated tornado data and the analysis provided in NUREG/CR-4661, the staff concluded (in SECY-93-087) that it is acceptable to reduce the tornado design basis wind speeds to $322 \mathrm{kilometers}$ per hour ( $\mathrm{km} / \mathrm{hr}$ ) $(200 \mathrm{mph})$ for states west of the Rocky Mountains and to $482 \mathrm{~km} / \mathrm{hr}$ (300 mph) for states east of the Rocky Mountains. The staff, therefore, concludes that the licensee's proposed reduction in design basis tornado wind speed to 200 mph is acceptable for WNP-2 which is located west of the Rocky Mountains. The licensee's proposed pressure drop and rate of pressure drop associated with the $200 \mathrm{mph}$ tornado are also acceptable because they are consistent with the design basis tornado characteristics found acceptable to the staff in Table 2-1 of NUREG-1503.

The licensee also proposea to revise che design basis tornado missile spectrum associated with the revised design basis tornado for WNP-2. The licensee calculated the impact velocities for the proposed tornado missile spectrum based on the reduced wind speed of $200 \mathrm{mph}$. The licensee's proposal used Missile Spectrum II identified in Section 3.5.1.4 of the Standard Review Plan (SRP). Because the missile spectrum is consistent with Section 3.5.1.4 of the SRP, the staff concludes that it is acceptable.

It should also be recognized that the tornado design basis requirements have been used in establishing structural requirements (minimum concrete wall thicknesses) for the protection of safety-related structures, systems, and components against effects not covered explicitly in review guidance such as regulatory guides and the Standard Review PIan. Specifically, some aviation (general aviation light aircraft) crashes, nearby explosions, and explosion debris or missiles have been reviewed and evaluated routinely by the staff by taking into account the existence of the tornado protection requirements. Therefore, for any new structures that are built using the revised tornado design criteria, the licensee should perform an analysis under 10 CFR 50.59 to verify that the structures are adequate, based on minimum wall thickness, have walls thick enough to protect against other postulated site-specific hazards or loads that may have been previously subsumed within the tornado design basis.

\subsection{CONCLUSIOPI}

Based on the above evaluation, the staff concludes that the licensee's proposed revised criteria for the design basis tornado are in accordance with the guidelines of RG 1.76 regarding the missile spectrum and with the staff's revised design basis tornado characteristics set forth in NUREG-1503. The staff, therefore, concludes that the proposed changes are acceptable.

\section{Principal Contributor: W. LeFave}

Date: January 24, 1996 